\title{
The Method to Create Transmission Lines and Increase the Power System Stability by Using Interconnection System Model
}

\author{
[Hartono, Ming-Tse Kuo, Yusraini Muharni ]
}

\begin{abstract}
Java-Bali system is weak. The power system stability needs to be increasing the $500 \mathrm{kV}$ transmission lines. The construction of the south transmission line, planned since 1996, has been hampered by land acquisition problems. Locals in Depok in West Java and in Klaten and Bantul, Central Java, have refused to make way for the power line.

A simulation by using Etap Power Station shows phenomena occurred during the blackout on August $18^{\text {th }} 2005$ the northern transmission line capacity extremely high (EHV) 500 KV transmission line Saguling-Cibinong (middle transmission line) is the only interconnected transmission line to invert electrical power from power station in East Java to West Java and Jakarta. The interconnection network along the Saguling-Cibinong transmission line cannot handle additional load since it almost reach its capacity limit. Moreover it is not flexible enough to supply power to Jakarta.

By adding the north transmission line Muaratawar-Cawang and Muaratawar-Cibinong, power supply from Muaratawar Steam Power Plant to Region 1 in third condition fifth phase will cause a large decreasing towards current line at the Saguling-Cibinong transmission line.
\end{abstract} line.

Keywords-blackout, security, EHV $500 \mathrm{KV}$, transmission

\section{Introduction}

Any disruption in the power interconnection system can affect the entire system. The worst impact that could be happened with the system is total, regional or partial blackout. As shown in Table I.

\section{Hartono}

University of Sultan Ageng Tirtayasa ${ }^{1}$

National Taiwan University of Science and Technology ${ }^{2}$ Indonesia $^{1}$, Taiwan ${ }^{2}$

Ming-Tse Kuo

National Taiwan University of Science and Technology

Taiwan

Yusraini Muharni

University of Sultan Ageng Tirtayasa ${ }^{1}$

National Taiwan University of Science and Technology 2

Indonesia $^{1}$, Taiwan ${ }^{2}$
TABLE I. LARGEST BLACKOUTS IN HISTORY [1][2][3]

\begin{tabular}{|c|c|c|c|c|}
\hline Ranked & Blackouts & $\begin{array}{c}\text { People } \\
\text { Affected }\end{array}$ & Location & Duration \\
\hline $1^{\text {st }}$ & Java-Bali & $100 \mathrm{M}$ & Indonesia & $2005-08-18$ \\
\hline $2^{\text {nd }}$ & $\begin{array}{c}\text { Southern } \\
\text { Brazil }\end{array}$ & $75 \mathrm{M}$ & $\begin{array}{c}\text { Brazil, South, } \\
\text { Southeastern }\end{array}$ & $1999-03-11$ \\
\hline $3^{\text {rd }}$ & $\begin{array}{c}\text { Brazil and } \\
\text { Paraguay }\end{array}$ & $60 \mathrm{M}$ & $\begin{array}{c}\text { Brazil and } \\
\text { Paraguay }\end{array}$ & $\begin{array}{c}2009-11-10 \\
2009-11-11\end{array}$ \\
\hline $4^{\text {th }}$ & Italy & $55 \mathrm{M}$ & Italy & $1999-03-11$ \\
\hline $5^{\text {th }}$ & Northeast 1 & $50 \mathrm{M}$ & $\begin{array}{c}\text { North America } \\
\text { Northeastern }\end{array}$ & $2003-08-14$ \\
$2003-08-15$ \\
\hline $6^{\text {th }}$ & Northeast 2 & $30 \mathrm{M}$ & $\begin{array}{c}\text { North America } \\
\text { Northeastern }\end{array}$ & $1965-11-09$ \\
\hline
\end{tabular}

About 100 million people, half of Indonesia's population got impact of power outage that cut electricity to homes, businesses and trains. It also caused major traffic jams in the capital city. A failure in $500 \mathrm{kV}$ transmission line between Cilegon and Saguling in West Java cuted electricity supplies at 10.23 a.m. The fault caused disengages several power plants units from the network. Two units of the Paiton plant in East Java and six units of the Suralaya plant in West Java were shut down.[1]

The weakness of Java and Bali power system is caused by the lack of spare power stations and minimal transmission line (at the time of blackout on August $18^{\text {th }} 2005$ in the interconnection between Java and Bali only relying on the middle section Saguling-Cibinong temporarily northern and southern section is still incomplete). The network in tact (middle section) cannot handle additional load since that event almost reach its capacity limit.

Java-Bali blackout system might be cause by several issues such as:

1. A transmission line between cilegon and saguling leads to cascading failure.

2. Two units of the paiton plant in east java and six units of the suralaya plant in west java.

3. Loss of $2300 \mathrm{MW}$ of generation that is roughly half of the supply.

4. Deficit of power due to low generation.

Lesson learnt:

1. Adequate generation to meet the needs

2. Adequate transmission line to withdraw power if $\mathrm{N}-1$ Security fails. 
The experts described this research on the investigation of grid blackouts. Operational mechanisms in the first condition should still be tried to maintain so that the transmission current line meets the $\mathrm{N}-1$ criteria. If the first condition criterion is met, the current Saguling-Cibinong should be limited to 1000 A on each transmission line. Recommendations made in this study is regarding possibility of adding new lines of EHV 500 $\mathrm{kV}$ most optimal. Most effective how many transmission line should be build to maintain the system stability in the future.

\section{Modeling Case}

\section{A. Case Study by Using the Java-Bali System}

Data transmission system buses Java-Bali $500 \mathrm{kV}$ are classified as follows:

a. Swing Bus: Saguling.

Saguling EHV voltage is voltage in the actual Conditions of the most stable and connected in AGC (automatic governor control).

b. Controller Bus: Cirata, Muara Tawar, Suralaya, Gresik, Tanjung Jati, Grati, and Paiton.

c. Load Bus: Cilegon, Kembangan, Gandul, Cibinong, Cawang, Bekasi, Cibatu, South London, Mandiracan, Ungaran, West Surabaya, Depok, Tasikmalaya, Pedan, Kediri.

\section{B. Algorithm to Maintain the System Stability in the Future Models}

The simulation performed during this research is based on the occurrence of trouble pursuant to the electrical blackout of the Java-Bali system on August $18^{\text {th }} 2005$. It compiled of the following conditions:

1) Transfer power of the Saguling-Cibinong line EHV only represents the main line running from East Java to West Java.

2) A simulation related to the first condition, in which there is a EHV Line Saguling-Cibinong, also an additional EHV southern line on the Tasik-Depok-Gandul 2 circuit.

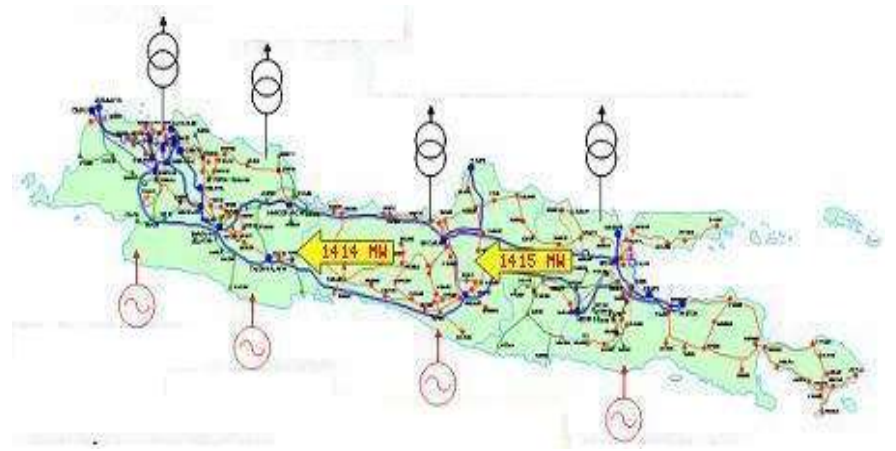

Figure. 1. Single line diagram
3) A simulation related to the first condition, in which there is a EHV Line Saguling-Cibinong, as well as an additional EHV Line Northern Muaratawar-Cibinong 1 circuit and Muaratawar-Cawang 1 circuit.

4) A simulation related to the first condition, where there is a Saguling-Cibinong transmission line, there is also an additional EHV North transmission line Muaratawar-Cibinong Circuit 1, a Muaratawar-Cawang circuit 1, and an additional EHV Southern Transmission line Tasik-Depok-Gandul.

5) A simulation related to the first condition, where there is a EHV Line Saguling-Cibinong trip, there's an additional EHV Northern Line Muaratawar-Cibinong Circuit 1, MuaratawarCawang Circuit 1, and also an additional EHV Southern Line Tasik-Depok-Gandul. Fig. 1 shows the area where the blackout occurred.

\section{What Caused The Blackouts?}

From each of the five conditions, there are six phases that have been adapted to the sequence which occurred during the JavaBali System blackout on August $18^{\text {th }} 2005$ as follows:

1. The first phase at 08:59 WIB

Before Suralaya Steam Power Plant Unit 6 and 7 trips, the power balance on Java Bali System was fulfilled at normal frequency with:

1. Region 1 Power station: $4744 \mathrm{MW}$

2. Region 2 Power station: $956 \mathrm{MW}$

3. Region 3 Power station: $791 \mathrm{MW}$

4. Region 4 Power station: 4517 MW

5. Total Java Bali system power station: $11008 \mathrm{MW}$.

2. Second phase at 08:59:27 WIB

Suralaya Unit 6 and 7 trips, Unit 5 run-back (decrease in power station capacity caused by disturbance) from $525 \mathrm{MW}$ to $220 \mathrm{MW}$.

Loss of 1359 MW power station power in Region 1.

3. Third phase at 09:00:09 WIB

Priok Steam Power Plant \#1.3 with DMN (netto power) 125 MW and Tambak Lorok Steam Power Plant ST 1.0 DMN 120 MW trip.

4. Fourth phase Load shedding

Decreased frequency System to with $48.6 \mathrm{~Hz}$ and happen automatic load shedding

Using UFR with total load released 335.25 MW with the following details:

- first phase to 5 Region 1 with total load released 281.76 MW

- 5 unit GI in Region 2 with total load released 32.71 MW

- 8 unit GI in Region 3 with total load released 10.52 MW

- 7 unit GI in Region 4 with total load released 10.26MW

Frequency increased and reached a normal frequency around the hour of 09:10 WIB.

5. Fifth phase at 09:10 WIB

To make up for the shortage of supply power in Region 1, P3B ran power station Saguling hydro power $2 \times 175$ MW, Cirata 4x125 MW, along with Muaratawar Blok 3 and 4.

6. Sixth phase at 10:23:30 WIB

EHV central line Saguling-Cibinong circuit 2 tripped causing circuit 1 to trip at the hour of 10:23:32 WIB. 


\section{Simulation by using Etap Power Station}

Input data is in need:

1. Active and reactive power load and generation at each bus.

2. Applied voltage at each node bus.

3. Impedance magnitude per kilometer of $500 \mathrm{kV}$ line

4. Large spacing between lines $500 \mathrm{kV}$ bus (kilometer)

The simulation by using an Etap Power Station requires predetermines parameter including number of iteration and precision. Higher number of iteration and precision requires longer computational time. Minimal number of iterations and the minimum level of precision that would require minimal effect on the results of calculations can converge on the run.

The result illustrating previous running in appropriate cases Model the incident electric power system blackout JavaBali on August 18th 2005 is shown in Fig. 2

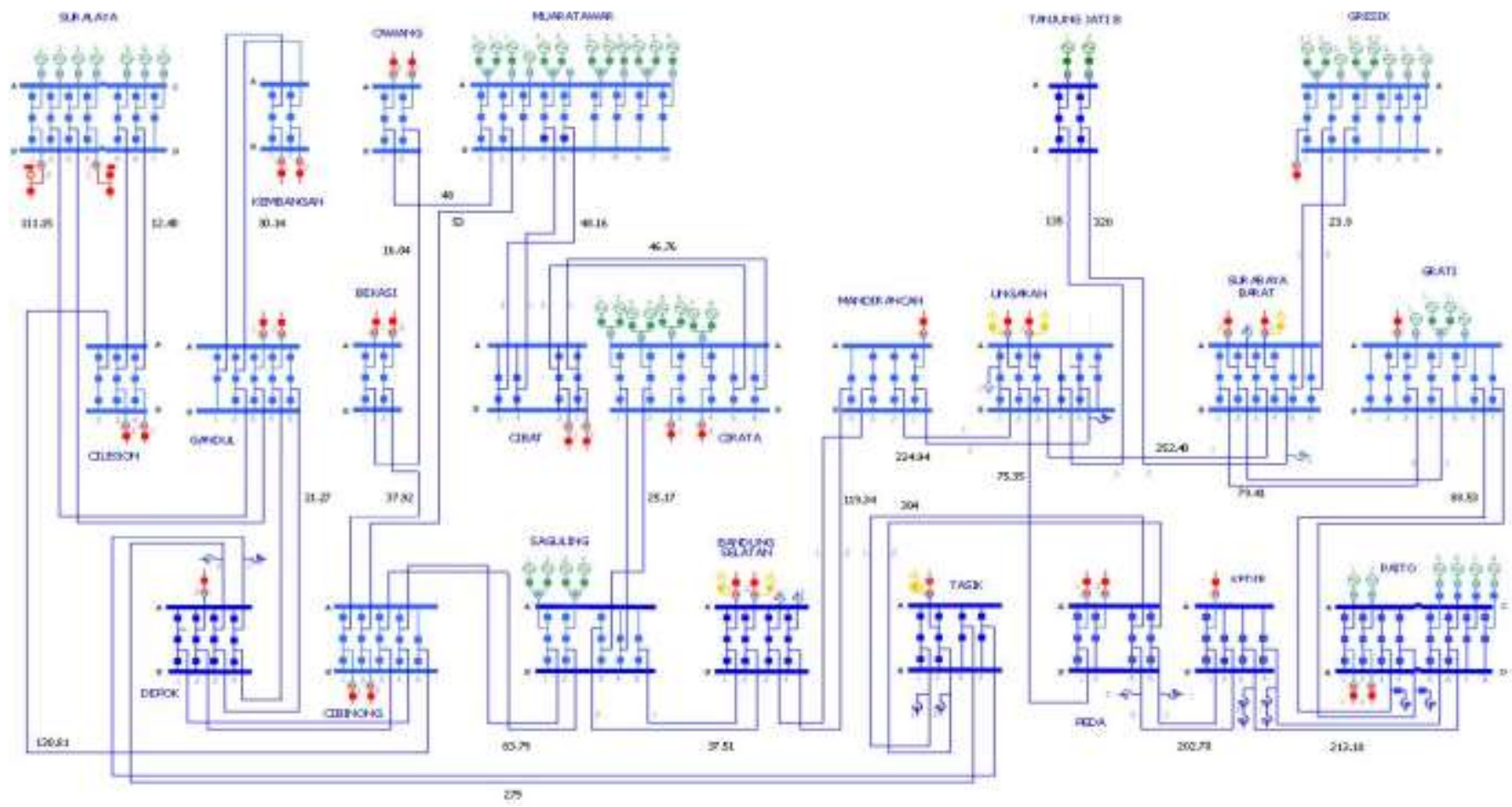

Figure. 2. Display network model by using software Etap Power Station

\section{v. Simulation Results}

Following are results of the electrical simulation conducted with software at the Etap Power Station. The maximum transmission lines limit in transmission line EHV Saguling-Cibinong 2 Circuit is 2.000 A (limited by the transformer current capacity installed). It means that current transmission line above 1000 A does not meet security N-1. This is caused by, in the case of transmission line current per circuit flowing above 1000 A then it will a trip will occur in Circuit 1 meaning the transmission line current will add on to the load of the first circuit until overload occurs at the second transmission line, causing both transmission lines to trip.

Based on the data shown in Table II. Additional of the EHV southern line at Depok-Gandul Circuit 2 in Second Condition tripped Circuit 2 Saguling-Cibinong at second phase and even third phase. However, adding EHV northern lines Muaratawar-Cibinong and Muaratawar-Cawang in third Condition might have prevented the blackout on August $18^{\text {th }}$ 2005.

All conditions show that $2^{\text {nd }}$ Phase and $3^{\text {rd }}$ Phase are the most vulnerable against the occurrence of a trip on the SagulingCibonong line from other phases.

Table II, also apparents that in $1^{\text {st }}$ condition, the trip incident on Circuit 2 of the Saguling-Cibinong line following $5^{\text {th }}$ Phase (blackout August $18^{\text {th }}$ 2005) could have been prevented by adding EHV northern lines MuaratawarCibinong and Muaratawar-Cawang, or adding the EHV southern line Depok-Gandul Circuit 2. 


\section{vi. Conclusion}

According to the aforementioned discussion, it can be concluded that:

1. Transfer of power between regions remains safe enough at first phase of all conditions since it has not yet surpassed the technical limits.
2. The configuration of the condition that met the $\mathrm{N}-1$ security criteria as simulated in this research are $3^{\text {rd }}$ condition and fourth condition. Third condition would be the most effective condition.

TABLE II. SIMULATION MATRIX CONDITION

\begin{tabular}{|c|c|c|c|c|c|c|}
\hline Event & Transmission line & $\begin{array}{l}\text { First Condition } \\
\text { current }(\mathrm{A})\end{array}$ & $\begin{array}{l}\text { Second Condition } \\
\text { current }(\mathrm{A})\end{array}$ & $\begin{array}{c}\text { Third Condition } \\
\text { current }(\mathrm{A})\end{array}$ & $\begin{array}{c}\text { Fourth Condition } \\
\text { current }(\mathbf{A})\end{array}$ & $\begin{array}{c}\text { Fifth Condition } \\
\text { current (A) }\end{array}$ \\
\hline First Phase & $\begin{array}{c}\text { Saguling-cibinong } \\
\text { Depok - Gandul } \\
\text { Muaratawar-cibinong } \\
\text { Muaratawar-cawang }\end{array}$ & 768 & $\begin{array}{l}302 \\
557\end{array}$ & $\begin{array}{r}453 \\
138 \\
531\end{array}$ & $\begin{array}{r}148 \\
547 \\
-70 \\
387\end{array}$ & $\begin{array}{l}562 \\
108 \\
498\end{array}$ \\
\hline Second Phase & $\begin{array}{l}\text { Saguling-cibinong } \\
\text { Depok-Gandul } \\
\text { Muaratawar-cibinong } \\
\text { Muaratawar-cawang }\end{array}$ & 1515 & $\begin{array}{c}1084 \\
436\end{array}$ & $\begin{array}{l}953 \\
\\
396 \\
718\end{array}$ & $\begin{array}{l}679 \\
414 \\
248 \\
602\end{array}$ & $\begin{array}{c}483 \\
955 \\
1133\end{array}$ \\
\hline Third Phase & $\begin{array}{c}\text { Saguling-cibinong } \\
\text { Depok-Gandul } \\
\text { Muaratawar-cibinong } \\
\text { Muaratawar-cawang }\end{array}$ & 1585 & $\begin{array}{c}1584 \\
-6\end{array}$ & $\begin{array}{l}996 \\
407 \\
754 \\
\end{array}$ & $\begin{array}{l}996 \\
-7 \\
407 \\
753 \\
\end{array}$ & $\begin{array}{c}-6 \\
1582 \\
1635\end{array}$ \\
\hline Fourth Phase & $\begin{array}{l}\text { Saguling-cibinong } \\
\text { Depok-Gandul } \\
\text { Muaratawar-cibinong } \\
\text { Muaratawar-cawang }\end{array}$ & 1406 & $\begin{array}{l}998 \\
418\end{array}$ & $\begin{array}{l}881 \\
\\
355 \\
684\end{array}$ & $\begin{array}{l}622 \\
398 \\
218 \\
573\end{array}$ & $\begin{array}{c}460 \\
862 \\
1060\end{array}$ \\
\hline Fifth Phase & $\begin{array}{l}\text { Saguling-cibinong } \\
\text { Depok-Gandul } \\
\text { Muaratawar-cibinong } \\
\text { Muaratawar-cawang }\end{array}$ & 1406 & $\begin{array}{l}886 \\
580\end{array}$ & $\begin{array}{l}776 \\
475 \\
773 \\
\end{array}$ & $\begin{array}{l}453 \\
556 \\
308 \\
625\end{array}$ & $\begin{array}{r}601 \\
759 \\
973\end{array}$ \\
\hline Sixth Phase & $\begin{array}{l}\text { Saguling-cibinong } \\
\text { Depok-Gandul } \\
\text { Muaratawar-cibinong } \\
\text { Muaratawar-cawang }\end{array}$ & 2044 & $\begin{array}{l}678 \\
702\end{array}$ & $\begin{array}{l}579 \\
\\
646 \\
828\end{array}$ & $\begin{array}{l}-200 \\
655 \\
294 \\
556\end{array}$ & $\begin{array}{l}654 \\
265 \\
546\end{array}$ \\
\hline
\end{tabular}

\section{Acknowledgment}

The authors would like to thanks to Dr.Ming-Tse Kuo for many helpful discussions pertaining to the work reported in our paper.

\section{References}

[1] www.wikipedia.org

[2] www.nrelect.com, PSCSTM : Power Stability Control System

[3] Prof Xinghuo Yu, Smart Grids : A Complex Network View, RMIT University, Australia 2011

[3] Mulyo Adji AG, Gambaran Umum Pengelolaan Electrical power system Java Bali, PT.PLN (Persero) Penyaluran and Pusat Pengatur Load Jawa Bali, 2005.
[4] G. Andersson, P. Donalek, R. Farmer, N. Hatziargyriou, I. Kamwa, P. Kundur, N. Martins, J. Paserba, P. Pourbeik, J. Sanchez-Gasca, R. Schulz, A. Stankovic, C. Taylor, and V. Vittal , Causes of the 2003 Major Grid Blackouts in North America and Europe, and Recommended Means to Improve System Dynamic Performance, IEEE Transactions ON Power Systems, Vol. 20, No. 4, November 2005.

[5] S. Corsi, C. Sabelli, General Blackout in Italy Sunday September 28, 2003, h. 03:28:00, IEEE 2003.

[6] John F.Hauer, Navin B.Bhatt, Kirit Shah, Sharma, Performance of "WAMS East 1 " in Providing Dynamic Information for the North East Blackout of August 14, 2003, IEEE 2003.

[7] A. Berizzi, The Italian 2003 blackout, IEEE 2003. 